\title{
Performance and metabolite profile of dairy cows fed tropical grasses and concentrates containing crude protein with low or high degradability
}

\author{
Raphael dos Santos Gomes ${ }^{1}$, Tadeu Silva de Oliveira', José Carlos Pereira ${ }^{2}$, Ricardo Augusto \\ Mendonça Vieira ${ }^{3}$, Douglas Sampaio Henrique ${ }^{4}$, Alberto Magno Fernandes ${ }^{3}$, Fernando de Paula \\ Leonel ${ }^{5}$
}

\author{
${ }^{1}$ Universidade Estadual do Norte Fluminense Darcy Ribeiro, Programa de Pós-graduação em Ciência Animal, Campos dos Goytacazes, RJ, Brazil. \\ 2 Universidade Federal de Viçosa, Departamento de Zootecnia, Viçosa, MG, Brazil. \\ ${ }^{3}$ Universidade Estadual do Norte Fluminense Darcy Ribeiro, Laboratório de Zootecnia, Campos dos Goytacazes, RJ, Brazil. \\ ${ }^{4}$ Universidade Tecnológica Federal do Paraná, Dois Vizinhos, PR, Brazil. \\ ${ }^{5}$ Universidade Federal de São João del Rei, Departamento de Zootecnia, São João del Rei, MG, Brazil.
}

\begin{abstract}
Ten Holstein-Zebu crossbred cows distributed into two simultaneous Latin squares $(5 \times 5)$ as a $2 \times 2$ factorial arrangement formed by chopped sugarcane or elephant grass silage, both with high or low protein degradability supplements and a corn silage as a control treatment, were compared using orthogonal contrasts. The studied variables were the performance, plasma concentrations of urea-N, glucose, and creatinine, urine-N and milk urea-N, and the nychthemeral variation in $\mathrm{NH}_{3}-\mathrm{N}$ in the rumen fluid of dairy cows. Nutrient intake, milk production, and milk composition were affected by the treatments. The total mixed ration containing elephant grass silage combined with rumen undegradable protein (RUP) provided balanced amounts of carbon and nitrogen in the rumen. This effect may explain the 18\% increase in milk yield compared with the other treatments. The diurnal pattern of ruminal $\mathrm{NH}_{3}-\mathrm{N}$ was interpreted with a sinusoid model. In general, cows fed elephant grass silage exhibited higher concentrations of blood plasma and milk urea-N than animals fed sugarcane. The cows that consumed elephant grass silage with rumen degradable protein concentrate showed a higher milk urea- $\mathrm{N}$ compared with animals that consumed elephant grass silage with the RUP concentrate. The use of diets based on corn silage leads to a better use of nitrogen compounds because these diets resulted in lower levels of urea-N in the plasma, urine, and milk at the same level of milk production compared with diets containing elephant grass silage or chopped sugarcane as roughages. In sugarcane-based diets, even greater nitrogen losses in the urine are observed, despite the presence of readily fermentable carbohydrates in the diet.
\end{abstract}

Key Words: intake, milk yield, nitrogen metabolites, tropical forages

\section{Introduction}

Rumen degradable protein (RDP) deficiency can limit microbial growth, especially when diets containing high concentrations of rumen undegradable protein (RUP) are provided (Nocek and Russell, 1988). This scenario leads to reduced ruminal digestion of the fibrous fraction of the feed and restrictions on feed intake due to the rumen fill effect of fiber (Mertens, 1987; Van Soest, 1994; Vieira et al., 2008a,b; Allen et al., 2009). By contrast, the use of RUP sources increases the flow of amino acids into the small intestine (Zinn and Owens, 1993). Such a strategy will be efficient every time the source of RUP shows a biological value superior to that of the microbial protein source

Received October 7, 2015 and accepted June 2, 2016

Corresponding author: ramvieira@uenf.br

http://dx.doi.org/10.1590/S1806-92902016000900010

Copyright (C) 2016 Sociedade Brasileira de Zootecnia. This is an Open Access article distributed under the terms of the Creative Commons Attribution License (http://creativecommons.org/licenses/by/4.0/), which permits unrestricted use, distribution, and reproduction in any medium, provided the original work is properly cited.
(AFRC, 1993; NRC, 2001). Rumen ammonia, in turn, derives from dietary protein degradation, the hydrolysis of non-protein nitrogen sources, rumen recycled urea, and the lysis of microbial cells. The concentration of rumen ammonia is an indicator of protein degradation, dietary nitrogen utilization, and microbial growth (Russell et al., 1992; Russell, 2002). Similarly, the blood urea concentration is a sensitive and immediate indicator of the animal protein metabolism, whereas the milk urea- $\mathrm{N}$ is a better indicator than blood urea for evaluating the metabolism of $\mathrm{N}$ compounds in the rumen because homeostatic mechanisms do not regulate milk urea- $\mathrm{N}$, a variable less affected by postprandial variations (Jonker et al., 1998). Considering the amino acid requirement of lactating animals and dietary amino acid supply, it is possible that RUP sources can promote better productive responses when combined with forages such as sugarcane or elephant grass silage. Sugarcane exhibits a pronounced imbalance of nutrients and is usually only supplemented with NPN (Fernandes et al., 2001), whereas both elephant grass and corn silages provide more protein and RDP levels (Cabral 
et al., 2000; Lacerda et al., 2004). Thus, it is possible that supplementation with RUP reduces ammonia production in the rumen (Seymour et al., 1992). Therefore, the present study aimed to evaluate the performance, the concentration of urea-N, glucose, and creatinine in blood plasma, urea-N in the urine and milk, and the pattern of diurnal variation of $\mathrm{NH}_{3}-\mathrm{N}$ in the rumen fluid of dairy cows fed chopped sugarcane or elephant grass silage, both supplemented with high and low RDP concentrates. A control diet based on corn silage was used as a reference.

\section{Material and Methods}

The experiment was conducted in the municipality of Bambuí $\left(20^{\circ} 00^{\prime} \mathrm{S}, 45^{\circ} 59^{\prime} \mathrm{W}\right.$, and elevation $661 \mathrm{~m}$ above the sea level), state of Minas Gerais, Brazil. The climate is Cwa (Kottek et al., 2006), with cold and dry winters and hot and humid summers. The monthly means (last 15 years) of dry-bulb temperature, wet-bulb temperature, relative humidity, rainfall, insolation, and wind speed were $23.6 \pm 2.4^{\circ} \mathrm{C}, 21.7 \pm 2.5^{\circ} \mathrm{C}, 73.5 \pm 6 \%, 110 \pm 119 \mathrm{~mm}, 5.9 \pm 1.4 \mathrm{~h}$, and $1.28 \pm 0.17 \mathrm{~m} \mathrm{~s}^{-1}$, respectively.

Ten Holstein-Zebu crossbred multiparous cows with a mean initial body weight of $535 \pm 66 \mathrm{~kg}$, producing on average $19.8 \pm 3.8 \mathrm{~kg} \mathrm{day}^{-1}$ of milk with a fat content of $36.1 \pm 3.8 \mathrm{~g} \mathrm{~kg}^{-1}$ of raw milk, were used. The experimental period was 115 days, for which the 10 initial days were intended for adapting the animals.

The experiment was distributed into two simultaneous Latin squares $(5 \times 5)$. Five cows between 24 and 40 days of lactation composed the first square, and the other square comprised five cows between 41 and 60 days of lactation. The experimental period was divided into five 21-day phases (14 days for adapting to the diets and seven days for sampling). Three different forages were the roughages used in the present study: corn silage, elephant grass silage, and chopped sugarcane. The five diets were the applied treatments, as follows: corn silage (CS) and conventional concentrate; elephant grass silage (EGS) combined with concentrate with RDP (EGS/RDP) or with RUP (EGS/RUP); and chopped sugarcane (SC) combined with concentrate with RDP (SC/RDP) or with RUP (SC/RUP). The experimental diets were formulated according to the CNCPS feed library (Fox et al., 1992; Russell et al., 1992; Sniffen et al., 1992), which contains crude protein and carbohydrate analyses and digestion and passage estimates of kinetic parameters that allow the calculations of RUP and RDP fractions and amounts to achieve the expected cow production levels of the present study. The diets were formulated to have forage: concentrate ratios on a dry matter basis of 780:220, 760:240, and 600:400 for CS, EGS, and SC, respectively (Tables 1 and 2). The body weights of the cows were measured by weighing the animals individually, with no previous fasting, after the morning milking at 5,6, and, 7 days of adaptation of each experimental period.

The total mixed rations were fed two times daily $(7.30 \mathrm{~h}$ and $16.30 \mathrm{~h})$ after milking, and were adjusted daily to maintain $10 \%$ leftovers. Before providing the morning feed, the leftovers from each experimental unit were collected, weighed, recorded, sampled, and stored in a freezer $\left(-10{ }^{\circ} \mathrm{C}\right)$. Samples of the corn silage, elephant grass silage, chopped sugarcane, and concentrates were also processed and stored in a similar manner. At the end of the experimental period, a total composite sample per animal/treatment was obtained.

The composite samples of each material (corn silage, elephant grass silage, sugarcane, concentrates, and leftovers) were used to determine the dry matter (DM, method number 967.03; AOAC, 1990), crude protein (CP, method number 984.13; AOAC, 1990), ash (method number 942.05; AOAC, 1990), crude fat (CF, method number 2003.06; Thiex et al., 2003), and lignin contents by solubilizing cellulose with $72 \% \mathrm{w} / \mathrm{w}$ sulfuric acid as lignin (sa) (method number 973.18; AOAC, 1990). The neutral detergent fiber (aNDF) was assayed with a heat-stable amylase and expressed inclusive of residual ash (Van Soest et al., 1991). The energy content was calculated according to the NRC (2001) equations.

Samples of rumen fluid $(500 \mathrm{~mL})$ were collected using an esophageal tube, at $0,2,4,6,8,10,12,14,16,18,20,22$, and $24 \mathrm{~h}$ after the morning feeding for determination of the diurnal pattern of rumen ammonia nitrogen $\left(\mathrm{NH}_{3}-\mathrm{N}\right)$. Rumen fluid collections were made in the minimum time required

Table 1 - Ingredients of the concentrates of the different diets

\begin{tabular}{lccc}
\hline \multirow{2}{*}{ Ingredient } & \multicolumn{3}{c}{ Concentrate $\left(\mathrm{g} \mathrm{kg}^{-1} \mathrm{DM}^{1}\right)$} \\
\cline { 2 - 4 } & Conventional & $\mathrm{RDP}$ & $\mathrm{RUP}$ \\
\hline Ground corn & 646 & 749 & 685 \\
Soybean meal & 246 & 190 & - \\
Corn gluten meal & - & - & 886 \\
Fish meal & - & - & 120 \\
Ground corn mature ears & - & - & 58 \\
Urea & - & 10 & - \\
Tallow & 47 & 30 & 29 \\
Premix & 61 & 21 & 22 \\
NaCl & 19 & 11 & 11 \\
Limestone & 12 & 3 & 4 \\
Mix ${ }^{2}$ & 30 & 6 & 6 \\
Mix2 $^{3}$ & - & 1 & 1 \\
\hline
\end{tabular}

RDP - rumen degradable protein; RUP - rumen undegradable protein

${ }^{1}$ Dry matter equal to $885.3 \mathrm{~g} \mathrm{~kg}^{-1}$ as fed.

${ }^{2}$ Contains: $230.00 \mathrm{~g} \mathrm{~kg}^{-1} \mathrm{Ca} ; 90 \mathrm{~g} \mathrm{~kg}^{-1} \mathrm{P} ; 20 \mathrm{~g} \mathrm{~kg}^{-1} \mathrm{Mg} ; 48 \mathrm{~g} \mathrm{~kg}^{-1} \mathrm{Na} ; 15 \mathrm{~g} \mathrm{~kg}^{-1} \mathrm{~S}$; $100 \mathrm{mg} \mathrm{kg}^{-1} \mathrm{Co} ; 700 \mathrm{mg} \mathrm{kg}{ }^{-1} \mathrm{Cu} ; 80 \mathrm{mg} \mathrm{kg}^{-1} \mathrm{I} ; 2,000 \mathrm{mg} \mathrm{kg}^{-1} \mathrm{Fe} ; 1,250 \mathrm{mg} \mathrm{kg}^{-1}$ Mn; $20 \mathrm{mg} \mathrm{kg}^{-1} \mathrm{Se} ; 2,700 \mathrm{mg} \mathrm{kg}^{-1} \mathrm{Zn} ; 200 \mathrm{IU} \mathrm{g}^{-1}$ vitamin A; $60 \mathrm{IU} \mathrm{g}^{-1}$ vitamin D3; $60 \mathrm{IU} \mathrm{kg}^{-1}$ vitamin E.

${ }^{3}$ Contains: $12,000 \mathrm{IU} \mathrm{g}^{-1}$ vitamin A; $1,800 \mathrm{IU} \mathrm{g}^{-1}$ vitamin D3; $54 \mathrm{IU} \mathrm{kg}^{-1}$ vitamin E. 
Table 2 - Chemical composition of roughage and treatments $\left(\mathrm{g} \mathrm{kg}^{-1} \mathrm{DM}\right)$

\begin{tabular}{|c|c|c|c|c|c|c|c|c|}
\hline \multirow{3}{*}{ Constituent } & \multicolumn{3}{|c|}{ Roughage } & \multicolumn{5}{|c|}{ Treatment } \\
\hline & \multirow{2}{*}{$\mathrm{CS}$} & \multirow{2}{*}{ EGS } & \multirow{2}{*}{$\mathrm{SC}$} & \multirow{2}{*}{$\mathrm{CS}$} & \multicolumn{2}{|c|}{ EGS } & \multicolumn{2}{|c|}{$\mathrm{SC}$} \\
\hline & & & & & RDP & RUP & RDP & RUP \\
\hline Dry matter ${ }^{1}$ & 400.0 & 230.0 & 312.0 & 506.0 & 384.0 & 385.0 & 541.0 & 543.0 \\
\hline Crude protein & 72.0 & 88.0 & 28.0 & 100.0 & 117.0 & 120.0 & 101.0 & 104.0 \\
\hline Rumen undegradable protein & - & - & - & 26.0 & 34.0 & 50.0 & 34.0 & 60.0 \\
\hline aNDF & 472.0 & 489.0 & 447.0 & 374.0 & 381.0 & 381.0 & 286.0 & 287.0 \\
\hline Lignin & 62.0 & 89.0 & 92.0 & 50.0 & 69.0 & 69.0 & 57.0 & 58.0 \\
\hline Crude fat & 19.0 & 25.0 & 10.0 & 29.0 & 31.0 & 32.0 & 22.0 & 23.0 \\
\hline Ash & 48.0 & 89.0 & 32.0 & 56.0 & 78.0 & 83.0 & 36.0 & 46.0 \\
\hline Metabolizable energy $^{2}$ & 9.74 & 8.31 & 8.68 & 10.54 & 9.63 & 9.58 & 10.73 & 10.64 \\
\hline
\end{tabular}

RDP - rumen degradable protein; RUP - rumen undegradable protein; CS - corn silage; EGS - elephant grass silage; SC - chopped sugarcane; aNDF - neutral detergent fiber. ${ }^{1} \mathrm{~g} \mathrm{~kg}^{-1}$ as fed.

${ }^{2} \mathrm{MJ} \mathrm{kg}^{-1}$.

to minimize saliva production by anxiety. Immediately after collection, the samples were filtered through a doublelayer cotton mesh. After filtration, $50 \mathrm{~mL}$ of sample were transferred to a polyethylene flask containing $1 \mathrm{~mL}$ of $50 \%$ $\mathrm{H}_{2} \mathrm{SO}_{4} \mathrm{w} / \mathrm{v}$, which was kept frozen at $-10{ }^{\circ} \mathrm{C}$ until the time of $\mathrm{NH}_{3}-\mathrm{N}$ determination via displacing $\mathrm{NH}_{3}-\mathrm{N}$ with excess $\mathrm{KOH}$, steam distillation, and titration with $0.005 \mathrm{M} \mathrm{HCl}$. The $\mathrm{NH}_{3}-\mathrm{N}$ concentrations determined at different collection times were used to fit time series models to characterize the profile of diurnal $\mathrm{NH}_{3}-\mathrm{N}\left(\mathrm{mg} \mathrm{dL}^{-1}\right)$ variation, as follows:

$Y_{i}=A_{0}+A_{1} \times \sin \left(c t_{i}\right)+A_{2} \times \cos \left(c t_{i}\right)+A_{3} \times \sin \left(2 c t_{i}\right)+A_{4} \times \cos \left(2 c t_{i}\right)$

Eq. (1), in which $Y_{i}$ represents the level of rumen $\mathrm{NH}_{3}-\mathrm{N}$ at time $t_{i}$; $c$ is a constant fraction of the fundamental period, which corresponds to $\pi \mathrm{rad} \mathrm{h}^{-1} ; t_{i}$ is the $\mathrm{i}$-th collection time; $A_{0}$ (mg dL ${ }^{-1}$ ) represents the mean $\mathrm{NH}_{3}-\mathrm{N}$ concentration; and $A_{1}, A_{2}, A_{3}$, and $A_{4}$ are scaling parameters that confer shape to the time profile. The circadian value of $c$ was set at 0.1309 $\mathrm{rad} \mathrm{h}^{-1}$, corresponding to $1 / 24$ of a fundamental period (Hopper et al., 1978).

On the 21st day of each experimental period, milk samples were collected during milking, and blood and urine samples were collected three hours after feeding to determine the levels of urea-N, glucose, and creatinine in the blood and urea- $\mathrm{N}$ in the urine and in milk. The urine sample was collected using a Foley catheter (Cunningham et al., 1955). Blood samples were collected from the mammary vein of each cow with vacuum tubes containing $100 \mu \mathrm{L}$ of sodium fluoride. The analyses of urea and glucose were performed using Ureia Enzimática (enzymatic urea) - Analisa ${ }^{\circledR}$ and Glicose Enzimática (enzymatic glucose) Analisa ${ }^{\circledR}$ enzyme kits. Fractions of composite milk samples were deproteinated using $25 \%$ trichloroacetic acid at a ratio of $5 \mathrm{~mL}$ to $10 \mathrm{~mL}$ of milk and filtered through filter paper to obtain $6 \mathrm{~mL}$ of serum. For the analyses of urea in milk serum and urine urea, a method similar to that employed for blood plasma was used, except that the urine samples were diluted at 1:50. The urea measurements were corrected for urea-N by multiplying by 0.47 .

Morning and afternoon milk production was measured every day and pooled to obtain an average daily production. One aliquot of $2 \%$ of each milking production was collected at days 7, 11, 15, and 19 of each experimental phase and placed in a $600-\mathrm{mL}$ plastic flask. The following parameters were determined in the milk samples: fat content, by the Gerber method (Kleyn et al., 2001); density, using a thermolactodensimeter calibrated to $15{ }^{\circ} \mathrm{C}$ and corrected for sample temperature; and $\mathrm{CP}$ content, by the Kjeldahl method (method number 984.13; AOAC, 1990). A factor of 6.38 was used to determine the $\mathrm{CP}$ content of the milk samples. The total milk solids (TMS) were estimated using the Fleischmann formula (Jost, 2000):

$$
\text { TMS }(g / k g)=1.2 \times f a t+26.65 \times((100 \times D)-100 / D)
$$

in which fat $=$ milk fat content $\left(\mathrm{g} \mathrm{kg}^{-1}\right)$, and $\mathrm{D}=$ milk density $\left(\mathrm{g} \mathrm{cm}^{-3}\right)$.

The DM and CP intake rates, urea-N concentrations, blood glucose, and creatinine, milk production, and milk constituents were analyzed by including treatments, square, period within square, and cow within square and the random error in the statistical model. The least-squares means for each treatment were requested. The treatments were compared using the following orthogonal contrasts: $\mathrm{CS} \times$ Others, EGS $\times \mathrm{SC}, \mathrm{EGS} / \mathrm{RDP} \times \mathrm{EGS} / \mathrm{RUP}$, and $\mathrm{SC} / \mathrm{RDP} \times \mathrm{SC} / \mathrm{RUP}$. The linear model was fitted by using the GLM procedure of SAS ${ }^{\circledR}$ software (Statistical Analysis System, version 9.0). P-values were considered significant whenever $\alpha<0.05$.

The Pearson correlation coefficient was used to measure the intensity of the linear correlation between the $\mathrm{CP}$ intake and the concentrations of urea-N, glucose, and creatinine in 
the blood plasma and urea-N in the urine, according to the CORR procedure of SAS ${ }^{\circledR}$ software (Statistical Analysis System, version 9.0).

\section{Results}

The lactation stage of the cows, represented by the square effect, did not affect the analyzed variables. The means of the recorded body weights of the cows were $526 \pm 64,523 \pm 67,542 \pm 65,521 \pm 73$, and $532 \pm 60 \mathrm{~kg}$ in the CS, EGS/RDP, EGS/RUP, SC/RDP, and SC/RUP diet groups (treatments), respectively.

Animals fed corn silage consumed less fiber than the animals fed EGS and more than those fed sugarcane. The EGS $\times$ SC contrast for DMI scaled to the body weight of the animals was significant, and the animals consumed more of the diets containing elephant grass silage than the diets containing sugarcane. More of the SC/RDP treatment was consumed by the cows than the SC/RUP treatment (Table 3). Paralleling to DMI, the fiber intake rate by the animals fed elephant grass silage was higher than in the animals fed sugarcane. However, the animals that were fed sugarcane supplemented with concentrate containing RDP consumed more fiber than the animals fed the sugarcane diet containing RUP concentrate (Table 3 ).

In the model describing the diurnal pattern of variation in rumen $\mathrm{NH}_{3}-\mathrm{N}$ (Eq. 1), the intercept represents the mean rumen $\mathrm{NH}_{3}-\mathrm{N}$ concentration. Thus, it can be observed that diets with EGS provided a higher rumen ammonia concentration compared with the other diets, while CS showed a higher concentration than SC (Table 4).
The level of plasma urea-N was higher in cows fed elephant grass-based diets (Table 5). Plasma glucose was not influenced by the treatments, while the CS $\times$ Others contrast was significant for plasma creatinine and urine urea-N (Table 5). The contrasts involving the different roughage sources $(\mathrm{CS} \times$ Others and $\mathrm{EGS} \times \mathrm{SC})$ and protein degradability of elephant grass-based diets (EGS/RDP $\times$ EGS/RUP) were significant for milk urea-N, while protein degradability did not affect the milk urea-N concentration in cows that consumed SC as roughage (Table 5).

The first peak in the ammonia concentration for all diets occurred 0 to $6 \mathrm{~h}$ after the morning and evening feedings, after which it began to decline, reaching a minimum point at between 12 and $18 \mathrm{~h}$. The second peak occurred approximately between 24 and $30 \mathrm{~h}$, and it was assumed that this cycle repeats over time, assuming steady-state conditions (Figure 1).

The $\mathrm{CP}$ intake and urine urea-N showed no correlation $(\mathrm{P}=0.126)$. However, urine urea-N did show a positive correlation with blood urea-N of $0.55(\mathrm{P}<0.001)$ and with milk urea-N of $0.60(\mathrm{P}<0.001)$.

Milk production of cows receiving treatments containing EGS was higher than those cows receiving treatments containing SC; milk production of the animals consuming elephant grass silage with RUP was higher than in the animals consuming the same forage supplemented with RDP (Table 6$)$. The forage type $(\mathrm{CS} \times$ Others and EGS $\times \mathrm{SC})$ and rumen degradability of dietary protein in the diets with EGS $(E G S / R D P \times E G S / R U P)$ affected the milk fat content (Table 6). By contrast, the rumen protein degradability did not affect the milk fat content in the animals that consumed sugarcane $(\mathrm{SC} / \mathrm{RDP} \times \mathrm{SC} / \mathrm{RUP})$. The milk protein content

Table 3 - Intakes of dry matter (DM), neutral detergent fiber (aNDF), and crude protein (CP) for cows fed diets with different roughage and protein sources with high and low ruminal degradability in $\mathrm{g} \mathrm{kg}^{-1}$ of body weight

\begin{tabular}{|c|c|c|c|c|c|c|c|c|c|c|}
\hline \multirow{3}{*}{ Variable } & \multicolumn{5}{|c|}{ Treatment } & \multirow{3}{*}{ SEM } & \multicolumn{4}{|c|}{$\mathrm{P}$-value for the contrasts } \\
\hline & \multirow{2}{*}{$\mathrm{CS}$} & \multicolumn{2}{|c|}{ EGS } & \multicolumn{2}{|c|}{$\mathrm{SC}$} & & \multirow{2}{*}{$1^{1}$} & \multirow{2}{*}{$2^{1}$} & \multirow{2}{*}{$3^{1}$} & \multirow{2}{*}{$4^{1}$} \\
\hline & & RDP & RUP & RDP & RUP & & & & & \\
\hline $\mathrm{DM}$ & 24.85 & 26.10 & 26.32 & 25.74 & 21.03 & 0.976 & 0.93 & 0.001 & 0.80 & $<0.001$ \\
\hline aNDF & 9.84 & 10.54 & 10.61 & 7.87 & 6.44 & 0.755 & 0.001 & $<0.001$ & 0.83 & 0.001 \\
\hline $\mathrm{CP}$ & 2.46 & 3.56 & 3.65 & 2.6 & 2.19 & 0.237 & $<0.001$ & $<0.001$ & 0.39 & 0.001 \\
\hline
\end{tabular}

CS - corn silage; EGS - elephant grass silage; SC - chopped sugarcane; RDP - rumen degradable protein; RUP - rumen undegradable protein; SEM - standard error of the mean. ${ }^{1} 1=\mathrm{CS} \times$ Others; $2=\mathrm{EGS} \times \mathrm{SC} ; 3=\mathrm{EGS} / \mathrm{RDP} \times \mathrm{EGS} / \mathrm{RUP} ; 4=\mathrm{SC} / \mathrm{RDP} \times \mathrm{SC} / \mathrm{RUP}$

Table 4 - Fitted equations of the time series models for the observed concentration of ammonia nitrogen in the rumen fluid (mg $\mathrm{dL}^{-1}$ )

\begin{tabular}{llll}
\hline Treatment & \multicolumn{1}{c}{ Regression $^{1}$} & $\mathrm{R}^{2}$ \\
\hline CS & $\hat{\mathrm{Y}}_{\mathrm{T} 1}=6.400-0.351 \sin \left(\mathrm{ct}_{\mathrm{i}}\right)-2.376 \cos \left(\mathrm{ct}_{\mathrm{i}}\right)+3.204 \sin \left(2 \mathrm{ct}_{\mathrm{i}}\right)+1.178 \cos \left(2 \mathrm{ct}_{\mathrm{i}}\right)$ & 0.06 & 0.06 \\
EGS/RDP & $\hat{\mathrm{Y}}_{\mathrm{T} 2}=11.281+0.130 \sin \left(\mathrm{ct}_{\mathrm{i}}\right)-3.825 \cos \left(\mathrm{ct}_{\mathrm{i}}\right)+1.400 \sin \left(2 \mathrm{ct}_{\mathrm{i}}\right)+3.106 \cos \left(2 \mathrm{ct}_{\mathrm{i}}\right)$ & 0.05 \\
EGS/RUP & $\hat{\mathrm{Y}}_{\mathrm{T} 3}=12.000-0.272 \sin \left(\mathrm{ct}_{\mathrm{i}}\right)-5.184 \cos \left(\mathrm{ct}_{\mathrm{i}}\right)+2.999 \sin \left(2 \mathrm{ct}_{\mathrm{i}}\right)+2.172 \cos \left(2 \mathrm{ct}_{\mathrm{i}}\right)$ & \\
SC/RDP & $\hat{\mathrm{Y}}_{\mathrm{T} 4}=4.965-0.057 \sin \left(\mathrm{ct}_{\mathrm{i}}\right)+0.100 \cos \left(\mathrm{ct}_{\mathrm{i}}\right)+1.682 \sin \left(2 \mathrm{ct}_{\mathrm{i}}\right)+1.248 \cos \left(2 \mathrm{ct}_{\mathrm{i}}\right)$ & 0.07 & \\
SC/RUP & $\hat{\mathrm{Y}}_{\mathrm{T} S}=5.296-0.726 \sin \left(\mathrm{ct}_{\mathrm{i}}\right)-1.377 \cos \left(\mathrm{ct}_{\mathrm{i}}\right)+2.174 \sin \left(2 \mathrm{ct}_{\mathrm{i}}\right)+1.377 \cos \left(2 \mathrm{ct}_{\mathrm{i}}\right)$ & 0.13 & \\
\hline
\end{tabular}

CS - corn silage; EGS - elephant grass silage; RDP - rumen degradable protein; RUP - rumen undegradable protein; SC - chopped sugarcane.

$\mathrm{c}$ is the fundamental period equal to $0.1309 \mathrm{rad} \mathrm{h}^{-1}$. 

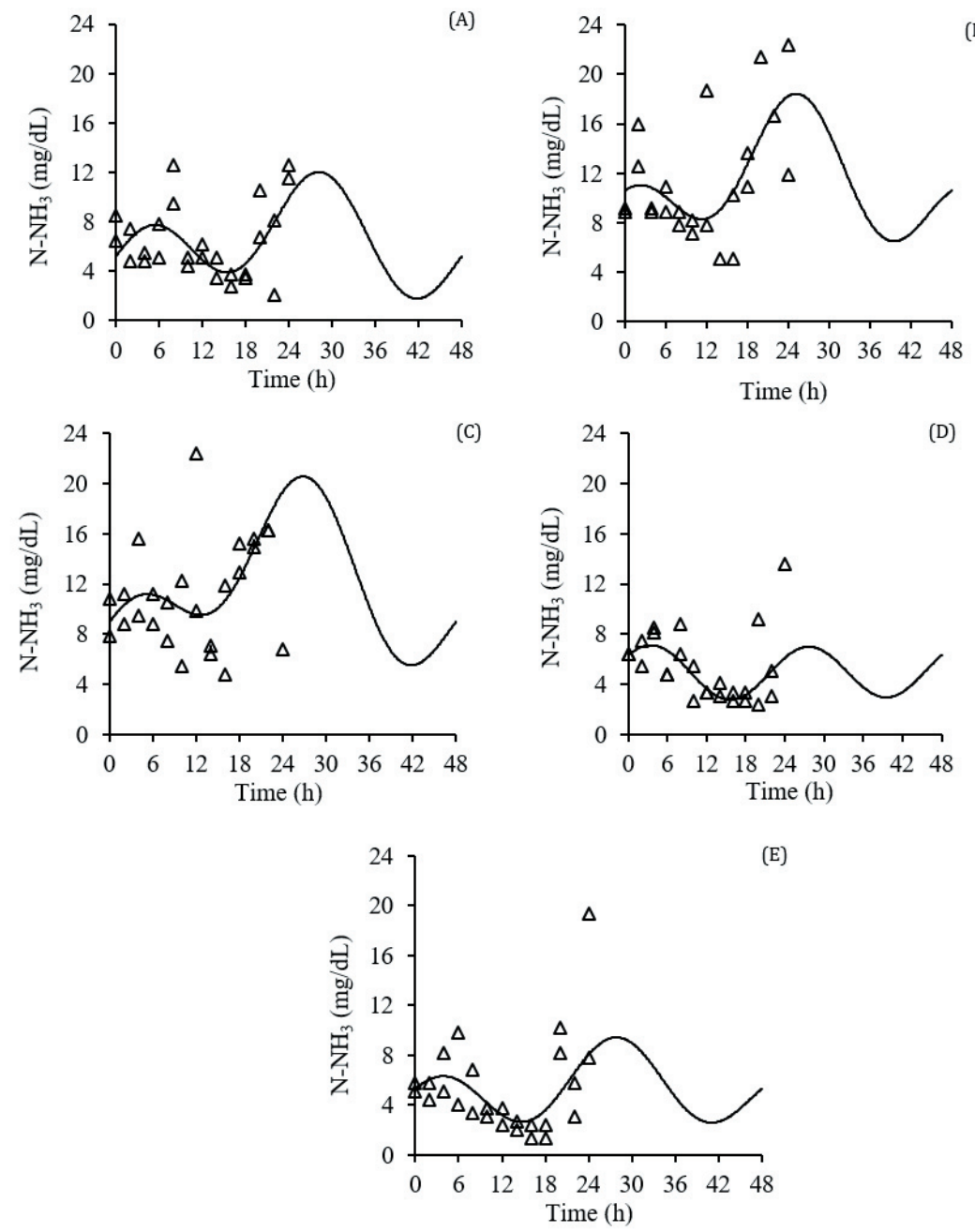

$\Delta$ - least squares means; solid lines - predicted values.

A - corn silage; B - elephant grass silage with rumen degradable protein; C - elephant grass silage with rumen undegradable protein; D - sugarcane with rumen degradable protein; E - sugarcane with rumen undegradable protein.

Figure 1 - Nycterohemeral patterns of ruminal ammonia nitrogen $\left(\mathrm{NH}_{3}-\mathrm{N}, \mathrm{mg} \mathrm{dL}^{-1}\right)$ in cows fed diets with different roughage types combined with protein sources with high and low ruminal degradabilities.

Table 5 - Contrasts among and least squares means of levels of metabolites in blood plasma, urine, and milk of cows fed diets with different roughage types and protein sources with high (RDP) and low (RUP) ruminal protein degradabilities

\begin{tabular}{|c|c|c|c|c|c|c|c|c|c|c|}
\hline \multirow{3}{*}{ Metabolite } & \multicolumn{5}{|c|}{ Treatment } & \multirow{3}{*}{ SEM } & \multicolumn{4}{|c|}{$\mathrm{P}$-value for the contrasts } \\
\hline & \multirow{2}{*}{ CS } & \multicolumn{2}{|c|}{ EGS } & \multicolumn{2}{|c|}{$\mathrm{SC}$} & & \multirow{2}{*}{$1^{1}$} & \multirow{2}{*}{$2^{1}$} & \multirow{2}{*}{$3^{1}$} & \multirow{2}{*}{$4^{1}$} \\
\hline & & RDP & RUP & RDP & RUP & & & & & \\
\hline $\mathrm{N}$-urea ${ }^{2}$ & 3.00 & 12.70 & 10.70 & 4.70 & 3.40 & 0.681 & 0.329 & 0.021 & 0.522 & 0.279 \\
\hline Glucose & 42.40 & 43.80 & 43.30 & 43.30 & 44.00 & 3.007 & 0.253 & 0.892 & 0.724 & 0.597 \\
\hline Creatinine & 1.16 & 1.09 & 1.04 & 1.04 & 1.03 & 0.139 & 0.035 & 0.495 & 0.456 & 0.899 \\
\hline \multicolumn{11}{|c|}{ Milk (mg dL $\left.{ }^{-1}\right)$} \\
\hline $\mathrm{N}$-urea & 2.30 & 11.30 & 8.60 & 3.70 & 2.60 & 2.250 & 0.001 & 0.001 & 0.013 & 0.275 \\
\hline
\end{tabular}

CS - corn silage; EGS - elephant grass silage; SC - chopped sugarcane; RDP - rumen degradable protein; RUP - rumen undegradable protein; SEM - standard error of the mean. ${ }^{1} 1=\mathrm{CS} \times$ Others; $2=\mathrm{EGS} \times \mathrm{SC} ; 3=\mathrm{EGS} / \mathrm{RDP} \times \mathrm{EGS} / \mathrm{RUP} ; 4=\mathrm{SC} / \mathrm{RDP} \times \mathrm{SC} / \mathrm{RUP}$.

2 These variables were transformed to meet the homoscedasticity criteria as $\log (\mathrm{y})$ and then rescaled to be presented. 
Table 6 - Milk yield and composition of cows fed diets with different roughage and protein sources with high (RDP) and low (RUP) ruminal protein degradability

\begin{tabular}{|c|c|c|c|c|c|c|c|c|c|c|}
\hline \multirow{3}{*}{ Variable } & \multicolumn{5}{|c|}{ Treatment } & \multirow{3}{*}{ SEM } & \multicolumn{4}{|c|}{ P-value for the contrasts } \\
\hline & \multirow{2}{*}{$\mathrm{CS}$} & \multicolumn{2}{|c|}{ EGS } & \multicolumn{2}{|c|}{$\mathrm{SC}$} & & \multirow{2}{*}{$1^{1}$} & \multirow{2}{*}{$2^{1}$} & \multirow{2}{*}{$3^{1}$} & \multirow{2}{*}{$4^{1}$} \\
\hline & & RDP & RUP & $\mathrm{RDP}$ & RUP & & & & & \\
\hline Milk yield & 14.70 & 13.76 & 16.40 & 14.44 & 13.92 & 1.226 & 0.868 & 0.03 & 0.001 & 0.35 \\
\hline $4 \%$ fat corrected milk & 13.66 & 13.84 & 16.03 & 13.46 & 13.16 & 1.086 & 0.235 & 0.001 & 0.001 & 0.547 \\
\hline \multicolumn{11}{|c|}{ Milk composition $\left(\mathrm{kg}\right.$ day $\left.^{-1}\right)$} \\
\hline Total milk solids & 1.82 & 1.74 & 2.07 & 1.79 & 1.72 & 0.157 & 0.849 & 0.005 & 0.001 & 0.278 \\
\hline \multicolumn{11}{|c|}{ Composition ( $\mathrm{g} \mathrm{kg}^{-1}$ of milk) } \\
\hline Fat & 35.00 & 41.00 & 39.00 & 36.00 & 37.00 & 1.988 & 0.001 & 0.001 & 0.025 & 0.439 \\
\hline Protein & 28.00 & 28.00 & 28.00 & 29.00 & 28.00 & 1.653 & 0.485 & 0.546 & 0.738 & 0.08 \\
\hline Total milk solids & 124.00 & 127.00 & 127.00 & 125.00 & 124.00 & 3.576 & 0.186 & 0.028 & 0.557 & 0.661 \\
\hline
\end{tabular}

CS - corn silage; EGS - elephant grass silage; SC - chopped sugarcane; RDP - rumen degradable protein; RUP - rumen undegradable protein; SEM - standard error of the mean. ${ }^{1} 1=\mathrm{CS} \times$ Others; $2=\mathrm{EGS} \times \mathrm{SC} ; 3=\mathrm{EGS} / \mathrm{RDP} \times \mathrm{EGS} / \mathrm{RUP} ; 4=\mathrm{SC} / \mathrm{RDP} \times \mathrm{SC} / \mathrm{RUP}$.

did not differ among the treatments, and the total milk solids content only differed when comparing the diets based on elephant grass silage and sugarcane $(\mathrm{EGS} \times \mathrm{SC})$.

\section{Discussion}

The low intake of the SC-based compared with the EGSbased diets may be related to the lower degradation and passage rates of SC, as reported by Fernandes et al. (2001). Waldo et al. (1972) proposed a model of interdependence among the intake, passage, and degradation rates that reinforces the causal relationship between the ruminal dynamics of digesta and nutrient intake of SC diets. Intake estimates based on this model proportionally increase with disappearance of the ruminal digesta, which occurs via degradation or escape of the potentially degradable fraction or via passage of the indigestible fraction. According to Poppi et al. (1981), the particles present in the rumen are reduced via chewing, ruminal movements, and microbial degradation until they reach a critical size of $1.18 \mathrm{~mm}$, at which point they escape the rumen. Lowdegradability feeds can take longer times to disappear from the rumen, causing rumen fill and reduced intake rates due to the pressure that the fibrous matter exerts on ruminal mechanoreceptors, which in turn send appetite-inhibiting signals to the central nervous system (Van Soest, 1994; Forbes, 1996; Leek, 2004).

Another factor that affects the DMI is the synchronization between the ruminal degradation of carbohydrates and nitrogenous compounds (Sniffen et al., 1992; Van Soest, 1994; Fox et al., 2004). When the peak protein availability does not occur simultaneously with the peak production of volatile fatty acids in the rumen (because of a greater amount of available carbohydrates), the efficiency of microbial protein production decreases, which can reduce microbial growth, reduce fiber degradation and turnover, and cause rumen fill (Van Soest, 1994). Thus, use of a RDP source combined with sugarcane promoted a higher DMI (Table 3). The use of the CNCPS model to evaluate diets is useful to estimate the nutritive value of different forage resources and other tropical foragebased diets (Cabral et al., 2000; Vieira et al., 2000a,b,c). The dietary synchronization is important for microbial growth and, depending on the availability of non-fibrous carbohydrates, the microbial biomass uses degradable nitrogen more efficiently (Russell et al., 1992; Malafaia et al., 1998; 1999; Vieira et al., 2000c; Favoreto et al., 2008; Fernandes et al., 2014). Because of the nutritional imbalances of sugarcane, e.g., high soluble sugars and low protein content, it should be used with caution to prevent excess nutrient losses (Fernandes et al., 2001).

Broderick (2003) stated that in addition to synchronizing the availability between carbon and nitrogen in the rumen, it is important to provide high-quality protein to be directly digested by the intestinal enzymes of the host. And for a synchronized supply between non-fiber carbohydrates and RDP to maintain the needs of the rumen microorganisms, RUP sources with high intestinal digestibility should also be adequately supplied to meet the metabolizable protein requirement of lactating cows. The animals that received elephant grass silage had higher milk production and higher yields of fat and total milk solids than those that received sugarcane due to the higher DM and CP intakes. This is most likely due to a better concurrent availability of energy substrates and $\mathrm{N}$ compounds in the rumen (AFRC, 1993; NRC, 1996; Broderick, 2003). 
In the EGS treatment, the animals that received RUP had higher milk production than those that received RDP, which may be associated with a higher availability of amino acids in the small intestine from digesting the protein that escaped microbial degradation in the rumen (Broderick, 2003). Huhtanen and Hristov (2009) and Ipharraguerre and Clark (2005) found that raising RUP levels of the diet is not necessarily associated with positive increments in milk production. Huhtanen and Hristov (2009) stated that one of the possible causes of these inconsistent responses to elevated dietary RUP levels may be related to an excess of metabolizable protein supply, i.e., in excess of the amount required. Therefore, actual amounts of RUP flowing to the intestines are usually in excess of the requirements of the cow. Castro et al. (2008) observed that large amounts of RUP are not associated with increases in either milk yield or $\mathrm{N}$ use by dairy cows fed alfalfa silage. It is possible that current models used to compute RUP amounts are biased to some extent by ignoring attributes (e.g., heterogeneity) of the ruminoreticular digesta (Huhtanen and Hristov, 2009).

Maximal rumen fermentation activity is achieved when rumen ammonia shows a concentration between 5 (Satter and Slyter, 1974) and $10 \mathrm{mg} \mathrm{dL}^{-1}$ (Van Soest, 1994). However, these values must not be considered fixed numbers because the uptake and use of ammonia for protein synthesis by bacteria depends on the rate of carbohydrate fermentation. Based on what was postulated by Van Soest (1994), the use of EGS-based feed results in an optimum rumen ammonia concentration (Table 4), which can be explained by higher protein intake (Tables 3 ). When a sugarcane-based diet was used, the mean concentration of $\mathrm{NH}_{3}-\mathrm{N}$ was close to $5 \mathrm{mg} \mathrm{dL}^{-1}$ of rumen fluid, which is considered a minimum value to maintain optimal levels of microbial growth (Satter and Slyter, 1974). It is worth noting that any $\mathrm{NH}_{3}-\mathrm{N}$ over this limit is not likely to be incorporated into microbial protein (Satter and Roffler, 1975).

The peak rumen ammonia concentration recorded in this study occurred from 3 to $6 \mathrm{~h}$ after feeding, a trend similar to that reported by Van Soest (1994). A drop in the rumen ammonia concentration occurred between 6 and $18 \mathrm{~h}$ after feeding, due either to the use of a portion of the ammonia for microbial protein synthesis or to absorption by the rumen epithelium, where ammonia is constantly absorbed into the bloodstream to be transferred to the liver and converted into urea, with associated energy expenditure. Urea can be recycled via saliva or it can be excreted in urine (Van Soest, 1994; Butler, 1998). Dairy cows fed diets containing dry rolled or pelleted barley combined with whole canola or whole flaxseed recycled from 58 to $65 \%$ of the urea $\mathrm{N}$ synthesized in the liver (Gozho et al.,
2008). Claypool et al. (1980) found that higher levels of plasma urea-N resulted from the use of diets with higher CP levels. In the present study, SC-based diets presented lower levels of plasma urea-N if compared with EGSbased diets. Therefore, differences in the availability of nitrogen and carbohydrate fractions in the rumen possibly influence $\mathrm{N}$ use, and the greater amount of protein in the EGS resulted in luxuriant RDP intake. The high content of soluble carbohydrates in SC may have favored the use of ammonia released during protein degradation by rumen microbes. Both ammonia metabolism in the liver and urea excretion by the kidneys incur an energy cost for the animal (NRC, 1996), which can reduce its productive performance. However, the milk production of animals that consumed EGS was higher than that of animals that consumed SC, despite the higher plasma urea-N concentration of EGS. Sugarcane exhibits a low nutritional value and high availability of sugars in the rumen, which may limit the general use of $\mathrm{N}$ compounds by the animal (Fernandes et al., 2001).

Glucose is responsible for countless functions in ruminant species, and a change in blood glucose is indicative of problems in the animal. According to Kahn and Line (2010), the range of variation in normal levels of blood glucose in cows is 42 to $72 \mathrm{mg} \mathrm{dL}-1$. Therefore, the blood glucose levels observed in the cows of the present study were considered normal and were not influenced by the treatments.

Creatinine excretion is little affected by the dietary levels of protein, non-fiber carbohydrates, or non-protein nitrogen (Ørskov and MacLeod, 1982). However, the animals fed corn silage exhibited higher creatinine excretion, which may be associated with the mobilization or deposition of reserves because creatinine results from protein metabolism in muscle tissue and its excretion scales to the amount of muscular tissue (Brody, 1945). However, as we did not evaluate the body composition of cows and a Latin square as the experimental design was adopted, we cannot conclusively affirm what may have caused the significant difference in creatinine excretion observed for the CS $\times$ Others contrast. Nonetheless, the P-values obtained for this variable using the applied frequentist statistical analysis were, from a Bayesian point of view, close to false positive detection levels (Johnson, 2013).

The urinary excretion of urea showed a correlation with plasma urea-N, despite the lack of consistency between treatment effects on serum and urine responses measured in this study (Table 5). Harmeyer and Martens (1980) and Ferreira et al. (2009) reported that the amount of urea excreted in urine is mainly influenced by the plasma urea 
concentration. Therefore, the $\mathrm{N}$ of EGS-based diets might have been used in a less conservative way by the cows in the present study.

According to Kauffman and St-Pierre (2001), an increase in the concentration of rumen ammonia results in a simultaneous increase in plasma urea and its consequent diffusion into the milk. The concentration of urea in milk is an indicator of the intensity of protein metabolism in cows (Jonker et al., 1998). In the present study, higher levels of milk urea-N were observed in association with the RDP diet only when EGS was used, most likely due to a rumen imbalance between nitrogen and energy availability resulting from the lower content of soluble carbohydrates in this forage source. The efficiency by which microorganisms in the rumen use nitrogen reflects on how the host also uses nitrogen; apparently, in this study, the corn silage-based diet contained a larger amount of synchronizable protein and carbohydrate fractions that might explain the lower observable plasma, milk, and urine urea-N.

\section{Conclusions}

Elephant grass silage combined with slow rumen degradable protein sources provides more nutrients so that lactating animals achieve a significant higher performance. This diet increases milk yield to approximately $18 \%$ more than diets based on sugarcane (rumen degradable and undegradable protein), elephant grass silage supplemented with rumen degradable protein, or corn silage-based diets.

The use of diets based on corn silage leads to better use of nitrogen compounds because these diets result in lower levels of urea nitrogen in plasma, urine, and milk at the same level as milk production, i.e., $14.7 \pm 0.97 \mathrm{~kg}$ day $^{-1}$, compared with diets containing elephant grass silage or sugarcane as forage sources. In sugarcane-based diets, greater nitrogen losses in the urine are observed, despite the greater availability of soluble and readily fermentable carbohydrates.

\section{Acknowledgments}

T. S. Oliveira thanks Fundação Carlos Chagas Filho de Amparo à Pesquisa do Estado do Rio de Janeiro - FAPERJ for the postdoctoral fellowship (case number E-26/101.429/ 2014) and Coordenação de Aperfeiçoamento de Pessoal de Nível Superior-CAPES (E-45/2013-PARDPJ). R. A. M. Vieira thanks Conselho Nacional de Desenvolvimento Científico e Tecnológico - CNPq for the grant provided (case number 304920/2015-0).

\section{References}

AFRC - Agricultural and Food Reaserch Council. 1993. Energy and protein requirements of ruminants. $\mathrm{CAB}$ International, Wallingford, UK.

Allen, M. S.; Bradford, B. J. and Oba, M. 2009. The hepatic oxidation theory of the control of feed intake and its application to ruminants. Journal of Animal Science 87:3317-3334.

AOAC - Association of Official Analytical Chemistry. 1990. Official methods of analysis. 15th ed. AOAC International, Arlington, VA.

Broderick, G. A. 2003. Effects of varying dietary protein and energy levels on the production of lactating dairy cows. Journal of Dairy Science 86:1370-1381.

Brody, S. 1945. Bioenergetics and growth. With special reference to the efficiency complex in domestic animals. Reinhold Publishing Co., New York.

Butler, W. R. 1998. Review: effect of protein nutrition on ovarian and uterine physiology in dairy cattle. Journal of Dairy Science $81: 2533-2539$.

Cabral, L. D.; Valadares, S. D.; Malafaia, P. A. M.; Lana, R. D.; Silva, J. F. C.; Vieira, R. A. M. and Pereira, E. S. 2000. Protein fractions of tropical feeds and their digestion rate estimated by means of incubation with ruminal protease. Revista Brasileira de Zootecnia 29:2316-2324

Castro, S. I. B.; Phillip, L. E.; Lapierre, H.; Jardon, P. W. and Berthiaume, R. 2008. The relative merit of ruminal undegradable protein from soybean meal or soluble fiber from beet pulp to improve nitrogen utilization in dairy cows. Journal of Dairy Science 91:3947-3957.

Claypool, D. W.; Pangborn, M. C. and Adams, H. P. 1980. Effect of dietary protein on high-producing dairy cows in early lactation. Journal of Dairy Science 63:833-837.

Cunningham, H. M.; Frederick, G. L. and Brisson, G. J. 1955. Application of an inflatable urethral catheter for urine collection from cows. Journal of Dairy Science 38:997-999.

Favoreto, M. G.; Deresz, F.; Fernandes, A. M.; Vieira, R. A. M. and Fontes, C. A. A. 2008. Avaliação nutricional da grama-estrela cv. Africana para vacas leiteiras em condições de pastejo. Revista Brasileira de Zootecnia 37:319-327.

Fernandes, A. M.; Deresz, F.; Henrique, D. S.; Lopes, F. C. F. and Glória, L. S. 2014. Nutritive value of Tanzania grass for dairy cows under rotational grazing. Revista Brasileira de Zootecnia 43:410-418

Fernandes, A. M.; Queiroz, A. C.; Lana, R. P.; Pereira, J. C.; Cabral, L. S.; Vittori, A. and Pereira, E. S. 2001. Estimativas da produção de leite por vacas holandesas mestiças, segundo o sistema CNCPS em dietas contendo cana-de-açúcar com diferentes valores nutritivos. Revista Brasileira de Zootecnia 30:1350-1357.

Ferreira, M. A.; Silva, R. R.; Ramos, A. O.; Véras, A. S. C.; Melo, A. A. S. and Guimarães, A.V. 2009. Síntese de proteína microbiana e concentrações de uréia em vacas alimentadas com dietas à base de palma forrageira e diferentes volumosos. Revista Brasileira de Zootecnia 38:159-165.

Forbes, J. M. 1996. Integration of regulatory signals controlling forage intake in ruminants. Journal of Animal Science 74:3029-3035.

Fox, D. G.; Sniffen, C. J.; O'Connor, J. D.; Russell, J. B. and Van Soest, P. J. 1992. A net carbohydrate and protein system for evaluating cattle diets. III. Cattle requirements and diet adequacy. Journal of Animal Science 70:3578-3596.

Fox, D. G.; Tedeschi, L. O.; Tylutki, T. P.; Russell, J. B.; Van Amburgh, M. E.; Chase, L. E.; Pell, A. N. and Overton, T. R. 2004. The Cornell Net Carbohydrate and Protein System model for evaluating herd nutrition and nutrient excretion. Animal Feed Science and Technology 112:29-78. 
Gozho, G. N.; Hobin, M. R. and Mutsvangwa, T. 2008. Interactions between barley grain processing and source of supplemental dietary fat on nitrogen metabolism and urea-nitrogen recycling in dairy cows. Journal of Dairy Science 91:247-259.

Harmeyer, J. and Martens, H. 1980. Aspects of urea metabolism in ruminants with reference to the goat. Journal of Dairy Science 63:1707-1728.

Hopper, J. T.; Holloway, J. W. and Butts, W. T. 1978. Animal variation in chromium sesquioxide excretion patterns of grazing cows. Journal of Animal Science 46:1096-1102.

Huhtanen, P. and Hristov, A. N. 2009. A meta-analysis of the effects of dietary protein concentration and degradability on milk protein yield and milk N efficiency in dairy cows. Journal of Dairy Science 92:3222-3232.

Ipharraguerre, I. R. and Clark, J. H. 2005. Impacts of the source and amount of crude protein on the intestinal supply of nitrogen fractions and performance of dairy cows. Journal of Dairy Science 88:E22-37.

Johnson, V. E. 2013. Revised standards for statistical evidence. Proceedings of the National Academy of Sciences 110:19313-19317.

Jonker, J. S.; Kohn, R. A. and Erdman, R. A. 1998. Using milk urea nitrogen to predict nitrogen excretion and utilization efficiency in lactating dairy cows. Journal of Dairy Science 81:2681-2692.

Jost, R. 2000. Milk and dairy products. Ullmann's Encyclopedia of Industrial Chemistry. Wiley-VCH, Weinheim.

Kahn, C. M. and Line, S. 2010. The Merck veterinary manual. Merck \& Co., Whitehouse Station, N.J.

Kauffman, A. J. and St-Pierre, N. R. 2001. The relationship of milk urea nitrogen to urine nitrogen excretion in Holstein and Jersey cows. Journal of Dairy Science 84:2284-2294.

Kleyn, D. H.; Lynch, J. M.; Barbano, D. M.; Bloom, M. J. and Mitchell, M. W. 2001. Determination of fat in raw and processed milks by the Gerber method: collaborative study. Journal of AOAC International 84:1499-1508.

Kottek, M.; Grieser, J.; Beck, C.; Rudolf, B. and Rubel, F. 2006. World map of the Köppen-Geiger climate classification updated. Meteorologische Zeitschrift 15:259-263.

Lacerda, P. D.; Malafaia, P.; Vieira, R. A. M.; Henrique, D. S.; Van Der Made, I. E. and Faria, A. R. G. 2004. Variação anual da composição bromatológica de duas forrageiras cultivadas nas baixadas litorâneas do Estado do Rio de Janeiro, Brasil. Ciência Rural 34:523-529.

Leek, B. F. 2004. Digestion in the ruminant stomach. p.438-474. In: Dukes' physiology of domestic animals. Reece, W. O., ed. Cornell University Press, Ithaca.

Malafaia, P. A. M.; Valadares Filho, S. C. V. and Vieira, R. A. M. 1999. Kinetic parameters of ruminal degradation estimated with a non-automated system to measure gas production. Livestock Production Science 58:65-73.

Malafaia, P. A. M.; Valadares Filho, S. C.; Vieira, R. A. M.; Silva, J. F. C. and Pereira, J. C. 1998. Determinação das frações que constituem os carboidratos totais e da cinética ruminal da fibra em detergente neutro de alguns alimentos para ruminantes. Revista Brasileira de Zootecnia 27:790-796.

Mertens, D. R. 1987. Predicting intake and digestibility using mathematical models of ruminal function. Journal of Animal Science 64:1548-1558.

Nocek, J. E. and Russell, J. B. 1988. Protein and energy as an integrated system. relationship of ruminal protein and carbohydrate availability to microbial synthesis and milk production. Journal of Dairy Science 71:2070-2107.

NRC - National Research Council. 1996. Nutrient requirements of beef cattle. National Academy of Sciences, Washington, DC.
NRC - National Research Council. 2001. Nutrient requirements of dairy cattle. National Academy Press, Washington, DC.

Ørskov, E. R. and MacLeod, N. A. 1982. The determination of the minimal nitrogen excretion in steers and dairy cows and its physiological and practical implications. The British Journal of Nutrition 47:625-626.

Poppi, D.; Minson, D. and Ternouth, J. 1981. Studies of cattle and sheep eating leaf and stem fractions of grasses. 3. The retention time in the rumen of large feed particles. Australian Journal of Agricultural Research 32:123-137.

Russell, J. B. 2002. Rumen microbiology and its role in ruminant nutrition. James B. Russell ${ }^{\circ}$, Ithaca.

Russell, J. B.; O'Connor, J. D.; Fox, D. G.; Van Soest, P. J. and Sniffen, C. J. 1992. A net carbohydrate and protein system for evaluating cattle diets: I. Ruminal fermentation. Journal of Animal Science 70:3551-3561.

Satter, L. D. and Roffler, R. E. 1975. Nitrogen requirement and utilization in dairy cattle. Journal of Dairy Science 58:1219-1237.

Satter, L. D. and Slyter, L. L. 1974. Effect of ammonia concentration on rumen microbial protein production in vitro. British Journal of Nutrition 32:199-208

Seymour, W. M.; Polan, C. E. and Herben, J. H. 1992. In vivo degradation of protein in diets formulated for two degradabilities. Journal of Dairy Science 75:2447-2453.

Sniffen, C. J.; O’Connor, J. D.; Van Soest, P. J.; Fox, D. G. and Russell, J. B. 1992. A net carbohydrate and protein system for evaluating cattle diets. II. Carbohydrate and protein availability. Journal of Animal Science 70:3562-3577.

Thiex, N. J.; Anderson, S. and Gildemeister, B. 2003. Crude fat, hexanes extraction, in feed, cereal grain, and forage (Randall/ Soxtec/Submersion Method): Collaborative study. Journal of AOAC International 86:899-908.

Van Soest, P. J. 1994. Nutritional ecology of the ruminant. Cornell University Press, Ithaca.

Van Soest, P. J.; Robertson, J. B. and Lewis, B. A. 1991. Methods for dietary fiber, neutral detergent fiber, and nonstarch polysaccharides in relation to animal nutrition. Journal of Dairy Science 74:3583-3597.

Vieira, R. A. M.; Pereira, J. C.; Malafaia, P. A. M.; Queiroz, A. C.; Jordão, C. P. and Goncalves, A. L. 2000c. Simulation of the nutrient dynamics in the gastrointestinal tract: application and validation of a mathematical model for grazing cattle. Revista Brasileira de Zootecnia 29:898-909.

Vieira, R. A. M.; Pereira, J. C.; Malafaia, P. A. M.; Queiroz, A. C. and Gonçalves, A. L. 2000b. Fracionamento dos carboidratos e cinética de degradação in vitro da fibra em detergente neutro da extrusa de bovinos a pasto. Revista Brasileira de Zootecnia 29:889-897.

Vieira, R. A. M.; Pereira, J. C.; Malafaia, P. A. M.; Queiroz, A. C. and Gonçalves, A. L. 2000a. Fracionamento e cinética de degradação in vitro dos compostos nitrogenados da extrusa de bovinos a pasto. Revista Brasileira de Zootecnia 29:880-888.

Vieira, R. A. M.; Tedeschi, L. O. and Cannas, A. 2008a. A generalized compartmental model to estimate the fibre mass in the ruminoreticulum: 1. Estimating parameters of digestion. Journal of Theoretical Biology 255:345-356.

Vieira, R. A. M.; Tedeschi, L. O. and Cannas, A. 2008b. A generalized compartmental model to estimate the fibre mass in the ruminoreticulum: 2. Integrating digestion and passage. Journal of Theoretical Biology 255:357-368.

Waldo, D. R.; Smith, L. W. and Cox, E. L. 1972. Model of cellulose disappearance from the rumen. Journal of Dairy Science 55:125-129.

Zinn, R. A. and Owens, F. N. 1993. Ruminal escape protein for lightweight feedlot calves. Journal of Animal Science 71:1677-1687. 